\title{
SCREENING FOR ANXIETY DISORDERS AMONG SCHOOLCHILDREN WITH ASTHMA
}

Jasmina R. Milovanovic ${ }^{1}$, Katerina Dajic ${ }^{2,3}$, Anđelka Stojkovic ${ }^{2,4}$, Aleksandra Tomic Lucic ${ }^{5,6}$, Slobodan M. Jankovic ${ }^{1}$ and Sandra Matovic ${ }^{3}$ ${ }^{1}$ University of Kragujevac, Serbia, Faculty of Medical Sciences, Department of Pharmacology and Toxicology

${ }^{2}$ Clinical Center of Kragujevac, Serbia, Pediatrics Clinic

${ }^{3}$ University of Kragujevac, Serbia, Faculty of Medical Sciences, PhD student

${ }^{4}$ University of Kragujevac, Serbia, Faculty of Medical Sciences, Department of Pediatrics

${ }^{5}$ University of Kragujevac, Serbia, Faculty of Medical Sciences, Department of Internal Medicine

${ }^{6}$ Clinical Center of Kragujevac, Serbia, Internal Clinic

PROCENA ANKSIZNOZNIH POREMEĆAJA

KOD ŠKOLSKE DECE SA ASTMOM

Jasmina R. Milovanović ${ }^{1}$, Katerina Dajić ${ }^{2,3}$, Anđelka Stojković ${ }^{2,4}$, Aleksandra Tomić Lučić ${ }^{5,6}$, Slobodan M. Jankovići i Sandra Matović ${ }^{3}$

${ }^{1}$ Univerzitet u Kragujevcu, Srbija, Fakultet medicinskih nauka, Katedra za farmakologiju i toksikologiju ${ }^{2}$ Klinički centar Kragujevac, Srbija, Klinika za pedijatriju

${ }^{3}$ Univerzitet u Kragujevcu, Srbija, Fakultet medicinskih nauka, student doktorskih studija

${ }^{4}$ Univerzitet u Kragujevcu, Srbija, Fakultet medicinskih nauka, Katedra za pedijatriju

${ }^{5}$ Univerzitet u Kragujevcu, Srbija, Fakultet medicinskih nauka, Katedra za Internu medicinu

Klinički centar Kragujevac, Srbija, Klinika za internu medinu

Received / Primljen: 02. 11. 2017.

Accepted / Prihvaćen: 24. 03. 2018.

\section{ABSTRACT}

The aim of this study was to perform screening for anxiety disorders among children with asthma and to reveal factors associated with general anxiety disorder and its specific forms.

This was a cross-sectional study conducted among outpatients with asthma during routine visits to pediatricians. They were screened for anxiety disorders using SCARED selfreported questionnaire. Additional data were collected using specially designed questionnaire as well as the patient files. Statistical analysis was performed by the SPPS software using descriptive statistics and logistic regression.

Study population consisted mostly of schoolchildren $(n=58), 8-12$ years old, and adolescents (13-17 years) $(n=13)$. Approximately 33.8\% respondents were positive for general anxiety disorder. The most common were separation anxiety and social anxiety, recorded among $49.3 \%$ and $32.4 \%$ of patients, respectively. Generalized anxiety and panic/somatic disorder were recorded in the same percentage of patients (21.3\%), while avoiding school was the least frequent (14.08\%). Influence of numerous factors was tested, but only the following showed significant effects: peak expiratory flow test was associated with general anxiety disorder, patient's age and gender with $P D$, and living place, asthma control according to GINA and age on GAD. Parent's smoking was associated with $S A D$, age and patient's weight status with SPH, and GINA asthma control with SA.

These findings suggest that anxiety disorders are common among children and adolescents with asthma. Various factors can be associated with general anxiety disorder and its specific forms, but some of them being preventable as avoiding smoking in the family.

Keywords: asthma, children, adolescents, anxiety disorder, SCARED

\section{SAŽETAK}

Cilj ove studije je bio da izvrši procenu anksioznih poremećaja kod dece sa astmom kao i da otkrije faktore povezane sa opštom anksioznošću i njenim specifičnim formama.

Izvedena je studija preseka kod vanbolničkih pacijenata sa astmom tokom rutinske posete pedijatru, a ispitivanje anksioznih poremećaja je izvršeno upotrebom SCARED upitnika. Dodatni podaci su prikupljeni na osnovu posebno dizajniranog upitnika i podataka iz medicinske dokumentacije. Statistička analiza je izvedena korišćenjem SPPS softvera i upotrebom deskriptivne statistike i logističke regresije.

Studijska populacija sastojala se većinom od školske dece $(n=58)$, starosti od 8-12 godina $i$ adolescenata (13-17 godina) (n=13). Približno 33.8\% ispitanika je bilo pozitivno na anksiozni poremećaj. Najčeš́e su bile prisutne separaciona i socijalna anksioznost kod 49.3\% i 32.4\% pacijenata. Generalizovana anksioznost i panični poremećaj su zabeleženi u istom procentu (21.3\%), dok je izbegavanje škole najmanje frekventno (14.08\%). Ispitivan je uticaj brojnih faktora, ali su samo sledeći pokazali značajan efekat: test za vršni ekspirijumski protok bio je povezan sa opštom anksioznošću, godine i pol pacijenata sa paničnim poremećajem, mesto stanovanja, kontrola astme u skladu sa GINA klasifikacijom i godine pacijenata sa generalizovanom anksioznošću. Upotreba cigareta od strane roditelja je povezana sa separacionom anksioznošću, godine i stepen uhranjenosti pacijenata sa socijalnom fobijom, $i$ GINA kontrola astme sa izbegavanjem škole.

Ovi rezultati sugerišu da su anksiozni poremećaji često prisutni kod dece i adolescenata sa astmom. Različiti faktori mogu biti povezani sa opštom anksioznošću i njenim specifičnim formama, ali neki od njih mogu biti preventabilni kao što je izbegavanje pušenja u porodici.

Ključne reči: astma, deca, adolescenti, anksioznost, SCARED 


\section{ABBREVIATIONS}

BMI - body mass index FEV 1 - forced expiratory volume in the first second GAD - generalized anxiety GINA - Global Initiative for Asthma PD - panic/somatic disorder
PEF - peak expiratory flow

SA - school avoidance

SAD - separation anxiety

SCARED - Screen for Child Anxiety Related Disorders

SPH - social phobia

\section{INTRODUCTION}

Anxiety is one of the most common psychiatric disorders with high prevalence in childhood (6-20\%) and adolescence $(8 \%)$ (1). Also, more than $10 \%$ of this vulnerable population worldwide has some chronic illness including asthma (2). Due to occasional hospitalization, early onset, long term medication usage and limited social life, certain psychological problems can occur among children with bronchial asthma (3). Taken together, prevalence of psychiatric illness is significantly increased and its estimated value ranged from $28 \%$ to $34 \%$ in children with asthma (4).

In $20^{\text {th }}$ century, numerous studies have shown higher incidence of psychiatric problems among children with severe asthma in comparison to children without chronic illness $(4,5)$. The review published in 2008 reported that one third of children and adolescents with asthma had anxiety disorder as comorbidity (6). Researchers suggested that the same neurotransmitters involved in anxiety and depression also are included in bronchoconstriction and inflammation. Furthermore, symptoms of anxiety can decrease ability to receive optimal treatment of asthma. On the other hand, asthma with its symptoms may interfere with individual functioning and precipitate anxiety and depression (7).

Most of children develop symptoms of both asthma and anxiety before the age of 6 . It is important to treat anxiety early, in order to avoid serious consequences including social and additional mental problems (2). Moderate level of anxiety in children with asthma is necessary because indifference may cause ignoring symptoms and lack of adherence. In turn, excessive anxiety can cause medication overdose or inefficient asthma management due to paralyzing fear (8). Social anxiety is also common among children and adolescents with asthma $(9,10)$.

Until now, there were 28 scales developed for identifying anxiety in children with long term physical conditions. Screen for Child Anxiety Related Disorders (SCARED) is one of the most satisfactory scales for identification of anxiety in children and adolescents $(1,4)$. Psychometric properties of the SCARED have been examined in several cultural backgrounds including German, Chinese, South Africa, Italian, Brazilian, Persian and Arabian (11-13). Numerous studies indicated that the SCARED has good internal consistency, discriminatory and concurrent validity, and its scores correlated well with Spence Children's Anxiety Scale, the Youth Self Report and the Columbia Impairment Scale scores (13).
The aim of this study was perform screening for anxiety disorder among children with asthma and also to reveal factors associated with general anxiety disorder and its specific forms such as panic/somatic disorder (PD), generalized (GAD) and separation anxiety (SAD), social phobia $(\mathrm{SPH})$ and school avoidance (SA).

\section{METHODS}

\section{Study population}

This was a cross-sectional study conducted among outpatients with asthma during their routine visits to pediatricians at Pediatric Clinic, Clinical Center Kragujevac, Serbia. The study was approved by the Ethics Committee of the Clinical Center $\left(\mathrm{N}_{0} 01-8325,10.08 .2015\right.$.) and the investigation was conducted in accordance to the principles of the Helsinki Declaration from January to March 2015.

The study population consisted of schoolchildren and adolescents (8-17years) with previously physician-diagnosed asthma. Before seeing a physician, the participants and their parents were informed about the purpose of the study and the children were included only if they themselves agreed to participate and their parents gave written informed consent. In total, seventy-four SCARED and demographic questionnaires were completed and returned to the researchers.

\section{Questionnaires}

The SCARED is frequently used, self-reported questionnaire consisting of 41 items that were validated and culturally adapted to Serbian language (14). It is used to assess symptoms of childhood anxiety disorders during previous three months in children 8 to 18 years old. The original SCARED scale was developed by Birmaher et al. in 1999 (15). The scale has five subscales where each item is scored on a 3-point scale ( 0 not true or hardly ever true, 1 somewhat true or sometimes true, and 2 very true or often true): panic/somatic disorder (PD, 13 items), generalized anxiety disorder (GAD, 8 items), separation anxiety disorder (SAD, 8 items), social phobia (SPH, 7 items) and school avoidance (SA or school anxiety symptoms, 4 items) subscale. The total SCARED score is the sum of all 
41 items with possible range from 0 to 82 , where higher scores indicate presence of higher anxiety in children. The cut-off values of otal scale and its subscales are: $\geq 25$ for total SCARED, $\geq 7$ for PD, $\geq 9$ for GAD, $\geq 5$ for SAD, $\geq 8$ for $\mathrm{SPH}$, and $\geq 3$ for SA scale, respectively.

The data about total body weight, height, sex and age of patients, its living place and school success, hereditary predisposition (present or absent asthma in the family), parental smoking status (none, one or both) and a mean daily exposure to sunshine (cut-off value was one hour) were collected using special questionnaire made by the study investigators. The following data were collected from the patient files: values of biochemical tests (serum calcium, phosphate, concentrations of 25-hydroxy vitamin D3 or 25, OH vitamin D3 and a total serum immunoglobulin E), results of spirometry (forced expiratory volume in the first second or FEV 1 and peak expiratory flow or PEF), medication, exacerbation rate, allergy skin prick tests according to the European Academy of Allergy and Clinical Immunology: inhalant allergens (ten: mildew, tree pollen, house dust mite, cat and dog's hair, pollen ambrosia, Festuca preatense, Dermatophagoides, feathers and cockroach) and food allergens (fourteen: spinach, tomato, chicken yolk and white, sea fish, orange, pork meat, wheat flour, carrot, soya, peanut, peas, cow's milk and cocoa), and a degree of asthma control according to the Global Initiative for Asthma (GINA) classification (controlled, partially controlled and uncontrolled) as rated by the attending physicians $(16,17)$.

The data were described statistically at first, using measures of central tendency and dispersion. Univariate and multivariate logistic regression were used to identify factors significantly associated with anxiety. The HosmerLemeshow test was used to assess the performance of the logistic regression model. The SPPS software (version 18.0) was used to perform all calculations.

\section{RESULTS}

Total number of participants was seventy-four but both questionnaires were completed by seventy-one participants (97.26\% response rate). The study population consisted mostly from schoolchildren $(n=58), 8-12$ years old, and adolescents (13-17 years) $(n=13)$, with mean age of the total population being $10.5 \pm 2.33$ years. All children had previously physician-diagnosed asthma and a slightly higher percentage was in favor of males in relation to females ( $55 \%$ vs. $45 \%$ ). Both, body mass index (BMI) $\left(\mathrm{kg} / \mathrm{m}^{2}\right)$ and BMI percentiles were calculated in the target population. Weigh status of children and adolescents was estimated using BMI percentiles for age and sex according to the Center for disease control and prevention growth recommendations (underweight: BMI $<5$ th percentile, healthy weight: $\mathrm{BMI} \geq 5$ th to $<85$ th percentile, overweight: $\mathrm{BMI} \geq 85$ th to $<95$ th percentile and obesity: $\geq 95^{\text {th }}$ percentile). Our study population consisted from $5.63 \%$ underweight patients $(n=4), 64.79 \%$ healthy weight
Table 1. Characteristics of the study population

\begin{tabular}{|c|c|c|}
\hline Patients characteristics & $\begin{array}{l}\text { Mean } \pm \\
\text { standard } \\
\text { deviation }\end{array}$ & Range \\
\hline Number of patients & 71 & \\
\hline Age (years) & $10.49 \pm 2.33$ & $8-17$ \\
\hline Total body weight (kg) & $42.38 \pm 15.94$ & $20-92$ \\
\hline Body mass index $\left(\mathrm{kg} / \mathrm{m}^{2}\right)$ & $18.94 \pm 4.11$ & $13.64-30$ \\
\hline $\begin{array}{l}\text { Weigh status (BMI percentiles): } \\
\text { - underweight } \\
\text { - healthy weight } \\
\text { - overweight } \\
\text { - obesity }\end{array}$ & $\begin{array}{l}-4 / 71 \\
-46 / 71 \\
-9 / 71 \\
-12 / 71\end{array}$ & \\
\hline Gender (male/female) & $39 / 32$ & \\
\hline Living place (urban/village) & $48 / 23$ & \\
\hline School success & $4.57 \pm 0.7$ & $1-5$ \\
\hline $\begin{array}{l}25, \mathrm{OH} \text { vit } \mathrm{D} 3 \text { serum concentration } \\
(\mathrm{ng} / \mathrm{mL})\end{array}$ & $16.56 \pm 6.0$ & $4.6-31.37$ \\
\hline Serum calcium levels (mmol/L) & $2.46 \pm 0.08$ & $2.25-2.61$ \\
\hline Serum phosphate levels (mmol/L) & $1.45 \pm 0.19$ & $0.96-2.14$ \\
\hline Total serum Ig E (IU/mL) & $422.66 \pm 629.76$ & $2.69-3000$ \\
\hline Sun exposure $(<1 \mathrm{~h} />1 \mathrm{~h})$ & $51 / 20$ & \\
\hline Allergy skin tests $(+/-)$ & $55 / 16$ & \\
\hline Hereditary predisposition (yes/no) & $45 / 26$ & \\
\hline Parents smoking (yes/no) & $32 / 39$ & \\
\hline FEV1 (\%) & $97.36 \pm 11.13$ & 74.9-125.6 \\
\hline PEF (\%) & $91.38 \pm 13.69$ & $60.3-116.1$ \\
\hline Exacerbation rate per patient & $0.9 \pm 1.08$ & $0-3$ \\
\hline Montelukast (yes/no) & $32 / 39$ & \\
\hline H1 antihistamines (yes/no) & $10 / 61$ & \\
\hline Inhalation corticosteroids (yes/no) & $50 / 21$ & \\
\hline Azelastine/fluticasone (yes/no) & $5 / 66$ & \\
\hline $\begin{array}{l}\text { GINA asthma control (No of } \\
\text { patients): } \\
\text { - controlled } \\
\text { - partially controlled } \\
\text { - uncontrolled }\end{array}$ & $\begin{array}{l}-24 \\
-43 \\
-4\end{array}$ & \\
\hline
\end{tabular}

$(n=46), 12.68 \%$ overweight $(n=9)$ and $16.9 \%$ obesity patients $(n=12)$. Table 1 provides baseline characteristics of the patients.

Mean value of total SCARED score was 22.31 (range 4 -54) and presence of childhood anxiety disorders symptoms was found in twenty-four children (33.80\%). Mean scores of the subscales were: 4.57 for panic/somatic disorder (PD range 0-16), 5.27 for generalized anxiety disorder (GA range 0-17), 4.95 for separation anxiety disorder (SAD range 0-15), 6.38 for social phobia (SPH range 0-14) and 1.28 for school avoidance (SA range 0-7), respectively. According to the cut-off values of the subscales, separation anxiety $(49.3 \%, \mathrm{n}=35)$ and social anxiety $(32.4 \%, \mathrm{n}=23)$ were the most frequent. Generalized anxiety and panic/ somatic disorders (21.3\% both, $\mathrm{n}=15$ ) were moderately frequent, while avoiding school trait was the least frequent $(14.08 \%, \mathrm{n}=10)$. Results of this analysis are summarized in the Table 2. 
Table 2. Total scores of SCARED scale in the study population

\begin{tabular}{|l|c|c|}
\hline Scale & $\begin{array}{l}\text { Mean } \pm \\
\text { standard } \\
\text { deviation }\end{array}$ & $\begin{array}{l}\text { Present/ not } \\
\text { present }\end{array}$ \\
\hline SCARED total & $22.31 \pm 12.03$ & $24 / 47$ \\
\hline Panic/somatic disorder (PD) & $4.57 \pm 3.81$ & $15 / 56$ \\
\hline Generalized anxiety disorder (GAD) & $5.27 \pm 4.18$ & $15 / 56$ \\
\hline Separation anxiety disorder (SAD) & $4.95 \pm 3.82$ & $35 / 36$ \\
\hline Social phobia (SPH) & $6.38 \pm 3.13$ & $23 / 48$ \\
\hline School avoidance (SA) & $1.28 \pm 1.54$ & $10 / 61$ \\
\hline
\end{tabular}

Using logistic regression factors associated with values above the cut-offs on the SCARED scale and its five subscales were identified. The following independent variables for both the full scale and subscales were accounted for the logistic regression: age, gender, weight status (using BMI percentiles: underweight, healthy weight, overweight and obesity), school success, living place, hereditary predisposition, parental smoking, sun exposure, allergy skin prick test, serum levels of calcium, phosphate, total IgE and 25, OH vitamin D3, rate of exacerbations and test of lung function (FEV1 and PEF), use of medication against asthma (montelukast, $\mathrm{H} 1$ antihistaminics, inhalation corticosteroids and nasal spray with azelastine and fluticasone) and asthma control status according to the GINA classification. The results of the logistic regressions for both complete scale and its subscales are presented in the Table 3.

\section{DISCUSSION}

The results of the study demonstrated that anxiety disorder was present in one-third of out-patients with asthma (children and adolescents) using the self-reported SCARED questionnaire. In regard to different types of anxiety, the results showed that the most common were separation anxiety (in almost half of the respondents) and social anxiety (approximately 33\%). Both generalized anxiety and panic/somatic disorder were noted in a significantly smaller number of respondents (21\%), while avoiding school trait was observed only in ten children.

In accordance with our results, Busing et al. reported that separation anxiety was the most common diagnosis in pediatric patients with asthma compared to healthy subjects $(\mathrm{p}=0.059)(18)$. On the other hand, the study conducted on 74 children with asthma found presence of separation anxiety disorder in only $8.1 \%$, while panic disorder was the most frequently encountered (14.9\%) (19). Earlier studies showed that social anxiety was frequent among adolescents. Presence of asthma led to reduction of their social interactions due to impairment in physical or social activities (19-24- 20-25). Moreover, they often feared from rejection by peers or felt different and isolated. It is known that peers have very important role in development of identity and social interactions (9, 25-26).

Reverse correlation between peak expiratory flow and symptoms of anxiety found in our study was supported by

Table 3. Results of the logistic regression models

\begin{tabular}{|c|c|c|}
\hline Scale and its subscales & Logistic regression model quality & $\begin{array}{l}\text { Significant factors and its adjusted odd ratios } \\
\left(\mathrm{OR}_{\text {adjusted }}\right) \text { with } 95 \% \text { confidence interval }\end{array}$ \\
\hline SCARED total & $\begin{array}{l}\text { CSRS }=0.350 \\
\text { NKRS }=0.485 \\
\mathrm{HLT}=7.196\end{array}$ & $\begin{array}{l}\mathrm{PEF}=0.924(0.857-0.996) \\
\mathrm{p}=0.04\end{array}$ \\
\hline \multirow{2}{*}{ Panic/somatic disorder (PD) } & \multirow{2}{*}{$\begin{array}{l}\mathrm{CSRS}=0.357 \\
\mathrm{NKRS}=0.555 \\
\mathrm{HLT}=3.462\end{array}$} & $\begin{array}{l}\text { Age }=0.565(0.325-0.983) \\
p=0.043\end{array}$ \\
\hline & & $\begin{array}{l}\text { Gender }=22.835(1.608-324.379) \\
\mathrm{p}=0.021\end{array}$ \\
\hline \multirow{3}{*}{ Generalized anxiety disorder (GAD) } & \multirow{3}{*}{$\begin{array}{l}\mathrm{CSRS}=0.392 \\
\mathrm{NKRS}=0.610 \\
\mathrm{HLT}=3.578\end{array}$} & $\begin{array}{l}\text { Age }=0.384(0.156-0.941) \\
p=0.036\end{array}$ \\
\hline & & $\begin{array}{l}\text { Living place }=52.065(1.690-1604.072) \\
\mathrm{p}=0.024\end{array}$ \\
\hline & & $\begin{array}{l}\text { GINA }=75.328(1.060-5351.942) \\
p=0.047\end{array}$ \\
\hline Separation anxiety disorder (SAD) & $\begin{array}{l}\mathrm{CSRS}=0.351 \\
\mathrm{NKRS}=0.468 \\
\mathrm{HLT}=5.007\end{array}$ & $\begin{array}{l}\text { Parents smoking }=4.542(1.172-17.598) \\
\mathrm{p}=0.029\end{array}$ \\
\hline \multirow{2}{*}{ Social phobia (SPH) } & \multirow{2}{*}{$\begin{array}{l}\mathrm{CSRS}=0.230 \\
\mathrm{NKRS}=0.306 \\
\mathrm{HLT}=10.444\end{array}$} & $\begin{array}{l}\text { Age }=0.675(0.534-0.853) \\
p=0.001\end{array}$ \\
\hline & & $\begin{array}{l}\text { Weight status }=0.493(0.251-0.968) \\
\mathrm{p}=0.04\end{array}$ \\
\hline School avoidance (SA) & $\begin{array}{l}\text { CSRS }=0.281 \\
\text { NKRS }=0.506 \\
\text { HLT }=1.001\end{array}$ & $\begin{array}{l}\text { GINA }=209.365(1.693-25886.887) \\
p=0.03\end{array}$ \\
\hline
\end{tabular}

CSRS: Cox\& Snell R square, NKRS: Nagelkerke R square, HLT: Hosmer and Lemeshow test, PEF: peak expiratory flow, p: statistical significant. 
results of the study on adolescents with severe persistent asthma (10). In this study significant linear relationship between adolescents' asthma-related anxiety and their management of existing symptoms $(\beta=0.03, p=0.021)$ was observed, as higher level of anxiety was associated with more steps necessary to control existing symptoms (10).

Factors associated with the GAD in our study were: age (older children expressed less of general anxiety disorder); living place (children from rural areas had fewer symptoms of generalized anxiety disorder), and GINA classification concerning asthma control (better asthma control led to less symptoms of generalized anxiety disorder). Gentile in his study connected exposure of inner-city violence to parental mental health conditions and subsequent nicotine addiction, as environmental tobacco smoke could lead to development of childhood asthma (27). Also, children and its family living in the city are more exposed to stress. In a study among pediatric patients with mild, moderate and severe asthma, emotional factors and family dynamics were triggers for the disease attacks in 16\% of children with mild, $38 \%$ with moderate and $68 \%$ with severe asthma. Between severity of asthma and maternity anxiety no significant correlation was found. Disease duration was not associated to depression or anxiety (3). Literature data showed that frequency of anxiety disorder increased with age: $4.1 \%$ in children with asthma and $8.9 \%$ in adolescents with asthma $(7,19)$.

Control of asthma according to GINA was associated with avoidance of school (as the control of asthma gets better the school avoidance is less frequent). The study on high school students with symptoms of asthma reported significantly greater total social anxiety scores than in peers with no symptoms. In this study Social Anxiety Scale for Adolescents (SAS-A) and the Social Phobia and Anxiety Inventory for Children (SPAI-C) were used to diagnose anxiety (9). Additionally, children with well controlled asthma do not have increased risk of anxiety disorders, as it was shown in a study on 70 well-controlled asthmatics and 70 matched healthy controls (28).

Patient's age has proved to be protective against social phobia together with its weight status in our population. As previously mentioned, frequency of anxiety disorder increased with age and social anxiety is commonly reported disorder in adolescents $(7,19,20)$. Nowadays, literature data show that childhood obesity is global, epidemic and multi factorial health condition. Researchers also suggested that obese children and adolescent have a higher risk for many physical and psychological consequences $(29,30)$. Childhood obesity has complex etiology and it is associated with complex behaviors and outcomes, but the causal relationship as well as the mediated factors between obesity and children mental health, are not yet well established. Psychological consequences often included problems linked with quality of life, self-esteem, depression or anxiety in children and adolescent. Although literature data show a moderate level of evidence for a positive association between obesity and anxiety disorders, but a negative relationship has been also reported (31). Vila and co-authors suggested that was no correlation between severity of obesity and frequency of psychiatric disorders in population of 155 children, age 5-17 years (32). On the other hand, some studies indicated that obesity is associated with higher prevalence of asthma and wheezing symptom in adolescents or with an increased risk of having a dry night cough in children (33-35). Moreover, a large cross-sectional study using data from 43.297 children, aged 10 to 17 years, and BMI percentiles for gender and age, indicated that asthma and allergies were more common in obese children (36). Study conducted in the Netherlands among children ages 11 to 16.3 showed the relationship between self-reported social anxiety and the severity of respiratory symptoms (37).

In our study children with a parent-smoker showed higher level of separation anxiety disorder than children of non-smokers. This is supported by a review about the relationship between environmental tobacco smoke exposure (ETS) and childhood respiratory disease. Key findings were that up to $70 \%$ of children are exposed to environmental tobacco smoking globally. Maternal smoking and ETS exposure has adverse influence on lung development of infants and are associated with upper and lower respiratory tract infection in childhood, wheezing or asthma. Environmental tobacco smoke exposure reduces lung function early in life, establishing an increased lifelong risk of respiratory diseases (38).

Girls in our study showed correlation to panic/somatic disorder more than boys, and age also was a significant factor in logistical regression model (older children had less panic/somatic disorder). This is proven in our small sample. Katon et al. reported that a prevalence of panic disorder or agoraphobia has been varied between $0.6 \%$ and $4.7 \%$ among asthmatic children (39). Female gender was also one of the factors that significantly increased risk of several disorders concerning anxiety that was in accordance to our results (40).

Results of the current study indicated no association between serum concentrations 25,OH vitamin D3 and anxiety in asthmatic children. Previous studies also showed that vitamin D supplementation or deficiency status were not related to anxiety in young adults $(41,42)$. Our findings did not found correlation between any allergy skin prick test and anxiety disorders using SCARED scale. However, the study on 80 children (mean age 8.1 years) showed that food allergies in children with asthma were associated with anxiety, using Multidimensional Anxiety Scale for Children (MASC) Total $(p=0.007)$, MASC Humiliation Rejection, $(\mathrm{p}=0.02)$ and MASC Social Anxiety scales $(\mathrm{p}=0.02)(43)$.

The main limitation of our study was small number of respondents (a total sample of 71 children and adolescents with asthma). Attitudes, worries and behaviors of parents were not taken into account in our study, although these could be important confounders hidden in the background of some of the identified risk factors. 
In conclusion, anxiety disorders, especially separation anxiety and social anxiety, are common among children and adolescents with asthma. Various factors can be associated with general anxiety disorder and its specific forms, but some of them being preventable as avoiding smoking in the family.

\section{ACKNOWLEDGEMENTS}

This work was supported by the Grants No JP 05-16 and No 175007 given by Faculty of Medical Sciences, University of Kragujevac and Serbian Ministry of Education, respectively.

\section{RERERENCES:}

1. Allison VL, Nativio DG, Mitchell AM, Ren D, Yuhasz J. Identifying symptoms of depression and anxiety in students in the school setting. J Sch Nurs. 2014; 30(3): 165-72.

2. Petrovic-Dovat L, Fausnight T, White AM, Zeiger T, Bansal PS, Garg N et al. Degree of anxiety in food allergic children in a tertiary care center. Ann Allergy Asthma Immunol. 2016; 116(6): 528-32.

3. Akçakaya N, Aydogan M, Hassanzadeh A, Camcioglu Y, Cokugraş H. Psychological problems in Turkish asthmatic children and their families. Allergol Immunopathol. 2003; 31(5): 282-87.

4. Thabrew H, McDowell H, Given K, Murrell K. Systematic Review of Screening Instruments for Psychosocial Problems in Children and Adolescents With Long-Term Physical Conditions. Glob Pediatr Health. 2017; 4: 1-25.

5. Vila G, Nollet-Clemençon C, de Blic J, Mouren-Simeoni MC, Scheinmann P. Prevalence of DSM IV anxiety and affective disorders in a pediatric population of asthmatic children and adolescents. J Affect Disord. 2000; 58(3): 223-31.

6. Van Lieshout RJ, Macqueen G. Psychological factors in asthma. Allergy Asthma Clin Immunol. 2008; 4(1): 12-28.

7. McCauley E, Katon W, Russo J, Richardson L, Lozano P. Impact of anxiety and depression on functional impairment in adolescents with asthma. Gen Hosp Psychiatry. 2007; 29(3): 214-22.

8. Bruzzese JM, Unikel LH, Shrout PE, Klein RG. Youth and Parent Versions of the Asthma-Related Anxiety Scale: Development and Initial Testing. Pediatr Allergy Immunol Pulmonol. 2011; 24(2): 95-105.

9. Bruzzese JM, Fisher PH, Lemp N, Warner CM. Asthma and social anxiety in adolescents. J Pediatr. 2009; 155(3): 398-403.

10. Bruzzese JM, Reigada LC, Lamm A, Wang J, Li M, Zandieh SO et al. Association of Youth and Caregiver Anxiety and Asthma Care Among Urban Young Adolescents. Acad Pediatr. 2016; 16(8): 792-98.

11. DeSousa DA, Zibetti MR, Trentini CM, Koller SH, Manfro GG, Salum GA. Screen for child anxiety related emotional disorders: are subscale scores reliable? A bifactor model analysis. J Anxiety Disord. 2014; 28(8): 966-70.

12. Arab A, El Keshky M, Hadwin JA. Psychometric Properties of the Screen for Child Anxiety Related Emotional Disorders (SCARED) in a Non-Clinical Sample of Children and Adolescents in Saudi Arabia. Child Psychiatry Hum Dev. 2016; 47(4): 554-62.

13. Chan SM, Leung CH. Factor Structure of the Screen for Child Anxiety-Related Emotional Disorders (SCARED) in a Community Sample of Hong Kong Chinese Adolescents. Child Psychiatry Hum Dev. 2015; 46(5): 671-82.

14. Stevanovic D. Childhood depression and anxiety disorders in Serbia: a psychometric study of four screening questionnaires. Epidemiol Psychiatr Sci. 2012; 21(1): 111-16.

15. Birmaher B, Brent DA, Chiappetta L, Bridge J, Monga S, Baugher M. Psychometric properties of the Screen for Child Anxiety Related Emotional Disorders (SCARED): a replication study. J Am Acad Child Adolesc Psychiatry. 1999; 38(10): 1230-36.

16. Akdis C, Agache I (Eds). Global Atlas of Allergy. Zurich: The European Academy of Allergy and Clinical Immunology; 2014.

17. Global Initiative for Asthma Management and Prevention, 2017. Available from:

ginasthma.org. Last assessed: 15.10.2017.

18. Bussing R, Burket RC, Kelleher ET. Prevalence of anxiety disorders in a clinic-based sample of pediatric asthma patients. Psychosomatics. 1996; 37(2): 108-15.

19. Goodwin RD, Messineo K, Bregante A, Hoven CW, Kairam R. Prevalence of probable mental disorders among pediatric asthma patients in an inner-city clinic. J Asthma. 2005; 42(8): 643-47.

20. Kyngäs H. Support network of adolescents with chronic disease: adolescents' perspective. Nurs Health Sci. 2004; 6(4): 287-93.

21. KyngAs HA, Kroll T, Duffy ME. Compliance in adolescents with chronic diseases: a review. J Adolesc Health. 2000; 26(6): 379-88.

22. Price JF. Issues in adolescent asthma: what are the needs? Thorax. 1996; 51 Suppl 1: S13-7.

23. Fitzgerald D. Non-compliance in adolescents with chronic lung disease: causative factors and practical approach. Paediatr Respir Rev. 2001; 2(3): 260-67.

24. Randolph CC, Fraser B. Stressors and concerns in teen asthma. Allergy Asthma Proc. 1998; 19(4): 193-203.

25. Bruzzese JM, Bonner S, Vincent EJ, Sheares BJ, Mellins $\mathrm{RB}$, Levison MJ et al. Asthma education: the adolescent experience. Patient Educ Couns. 2004; 55(3): 396-406.

26. Buhrmester D, Furman W. The development of companionship and intimacy. Child Dev. 1987; 58(4): 1101-13.

27. Gentile D. Link between childhood asthma and mental health conditions. J Asthma.2008; 45 Suppl 1: 37-40.

28. Letitre SL, de Groot EP, Draaisma E, Brand PL. Anxiety, depression and self-esteem in children with wellcontrolled asthma: case-control study. Arch Dis Child. 2014; 99(8): 744- 48. 
29. Sagar R, Gupta T. Psychological Aspects of Obesity in Children and Adolescents. Indian J Pediatr. 2017; doi: 10.1007/s12098-017-2539-2.

30. De Niet JE, Naiman DI. Psychosocial aspects of childhood obesity. Minerva Pediatr. 2011; 63(6): 491-505.

31. Lykouras L, Michopoulos J. Anxiety disorders and obesity. Psychiatriki. 2011; 22(4): 307-13.

32. Vila G, Zipper E, Dabbas M, Bertrand C, Robert JJ, Ricour $\mathrm{C}$ et al. Mental disorders in obese children and adolescents. Psychosom Med. 2004; 66(3): 387-94.

33. Luder E, Ehrlich RI, Lou WY, Melnik TA, Kattan M. Body mass index and the risk of asthma in adults. Respir Med. 2004; 98(1): 29-37.

34. Kilpeläinen M, Terho EO, Helenius H, Koskenvuo M. Body mass index and physical activity in relation to asthma and atopic diseases in young adults. Respir Med. 2006; 100(9): 1518-25.

35. Vlaski E, Stavric K, Isjanovska R, Seckova L, Kimovska M. Overweight hypothesis in asthma and eczema in young adolescents. Allergol Immunopathol (Madr). 2006; 34(5): 199-205.

36. Halfon N, Larson K, Slusser W. Associations between obesity and comorbid mental health, developmental, and physical health conditions in a nationally representative sample of US children aged 10 to 17. Acad Pediatr. 2013; 13(1): 6-13.
37. Rietveld S, van Beest I, Prins PJ. The relationship between specific anxiety syndromes and somatic symptoms in adolescents with asthma and other chronic diseases. J Asthma. 2005; 42(9): 725-30.

38. Vanker A, Gie RP, Zar HJ. The association between environmental tobacco smoke exposure and childhood respiratory disease: a review. Expert Rev Respir Med. 2017; 11(8): 661-73.

39. Katon WJ, Richardson L, Lozano P, McCauley E. The relationship of asthma and anxiety disorders. Psychosom Med. 2004; 66(3): 349-55.

40. Peters TE, Fritz GK. Psychological considerations of the child with asthma. Pediatr Clin North Am. 2011; 58(4): 921-35.

41. Milovanovic OZ, Milovanovic JR, Djukic A, Matovic M, Lucic AT, Glumbic N et al. Variation in vitamin D plasma levels according to study load of biomedical students. Acta Pol Pharm. 2015; 72(1): 213-5.

42. Dean AJ, Bellgrove MA, Hall T, Phan WM, Eyles DW, Kvaskoff D te al. Effects of vitamin D supplementation on cognitive and emotional functioning in young adults - a randomised controlled trial. PLoS One. 2011; 6(11): e25966.

43. Goodwin RD, Rodgin S, Goldman R, Rodriguez J, deVos G, Serebrisky D et al. Food Allergy and Anxiety and Depression among Ethnic Minority Children and Their Caregivers. J Pediatr. 2017; 187: 258-264. 